\title{
MANAJEMEN DANA DESA DI DESA GIRIREJO KECAMATAN KALIANGKRIK, KABUPATEN MAGELANG TAHUN 2018
}

\author{
Anis Rahmawati ${ }^{1}$, Hendrarto ${ }^{2}$, Retno Dewi Pramodia Ahsani ${ }^{3}$ \\ 1,2,3 Program Studi Ilmu Administrasi Negara, Fakultas Ilmu Sosial dan Ilmu Politik \\ Universitas Tidar, Magelang \\ Jalan Kapten Suparman 39 Magelang 56116, Jawa Tengah, Indonesia \\ Email: ${ }^{1}$ anis.rahmawati007@gmail.com, ${ }^{2}$ hendrarto50@yahoo.co.id, \\ 3 pramodiaahsani@gmail.com
}

Article Histori:

Submited: $12 / 08 / 2019$

Editing: 02/10/2019

Publish: 21/10/2019

\section{Abstract}

This study discusses village fund management that was carried out at Girirejo Village, Kaliangkrik Subdistrict, Magelang Regency in 2018. The purpose of this study is to identify and analyze village fund management in Girirejo Village using management theory from G. R. Terry which consists of 4 aspects including ; (1) Planning ; (2) Organizing ; (3) Actuating ; (4) Controlling. This study used qualitative research methods with a case study approach. The result of this study is a village fund management at Girirejo Village hasbeen going well it can be seen from every aspect of management that is line with the objectives of the village fund program. Besides that village fund management in the Girirejo Village has also involved the community in several activities. Even though it has done well, village fund management in the Girirejo Village is still experiencing several obstacles, namely the problem of implementing activities that include weather, material, and terrain that is difficult to reach, thus it is affecting the village fund management in the Girirejo Village

Keyword: Management, Village, Village Fund.

\section{PENDAHULUAN}

Sejak diberlakukannya otonomi daerah, setiap daerah di Indonesia memiliki kewenangan dalam mengatur dan mengurus rumah tangga daerahnya masing-masing tidak terkecuali desa. Menurut UU No 6 Tahun 2014 tentang desa, desa diberikan hak-hak istimewa diantaranya terkait dengan pengelolaan keuangan dan alokasi dana desa, pemilihan kepala desa dan juga proses pembangunan desa itu sendiri. UU No 6 Tahun 2014 memberikan mandat kepada pemerintah untuk mengalokasikan dana desa. Dana desa merupakan salah satu sumber pendapatan desa yang berasal dari APBN pemerintah pusat yang diperuntukkan bagi desa dan ditransfer melalui APBD 
kabupaten/kota dan diprioritaskan untuk pelaksanaan pembangunan; dan pemberdayaan masyarakat desa. Program dana desa merupakan program yang digunakan untuk mengembangkan serta membangun desa, sehingga desa yang dahulunya terpinggirkan menjadi lebih diperhatikan dan lebih berkembang lagi. Dan desa yang memiliki kesan miskin, serta terpinggirkan dapat terganti dengan kesan desa yang maju dan bernilai positif dengan adanya pembangunan dan pemberdayaan masyarakat yang didanai oleh dana desa.

Kabupaten Magelang terdiri dari 21 kecamatan, 367 desa dan 5 kelurahan yang masuk kedalam 5 besar dalam memperoleh dana desa terbesar se Provinsi Jawa Tengah. Kecamatan Kaliangkrik memperoleh dana desa pada tahun 2108 sebesar Rp. 20.336.583.000. Desa Girirejo merupakan satu desa dari 20 desa di Kecamatan Kaliangkrik yang memperoleh dana desa Rp. 1091.491.000 pada tahun 2018. Perolehan dana desa tahun 2018 direncanakan digunakan Desa Girirejo seperti tabel 1.1. dibawah ini:

Tabel 1 Rencana Penggunaan Dana Desa

\begin{tabular}{|c|c|}
\hline Rencana Penggunaan Dana Desa & Besaran Dana Desa \\
\hline Pembangunan & Rp. 880.803 .000 \\
\hline Pemberdayaan Masyarakat & Rp. 136.688 .000 \\
\hline Total & Rp. 1.019.491.000 \\
\hline
\end{tabular}

Sumber : Perdes Girirejo, 2018.

Dari data rencana penggunaan dana desa di Desa Girirejo tahun 2018, Desa Girirejo merencanakan penggunaan dana desa secara optimal yang akan dimanfaatkan secara maksimal untuk pembangunan dan pemberdayaan masyarakat. Selain rencana penggunaan yang maksimal penyerapan dana desa di Desa Girirejo pada tahun 2018 juga sudah optimal.

Penyerapan dana desa di Desa Girirejo sudah cukup baik dan diserap secara optimal namun belum semuanya terbangun, seperti jalan poros yang menghubungkan antar dusun maupun jalan poros yang menghubungkan antar desa. Selain itu, desa juga masih banyak memiliki keterbatasan dalam organisasi pemerintahannya. Perbedaan dalam penggunaan dana desa yang direncanakan dengan realisasi penggunaan dana desa di Desa Girirejo Tahun 2018 juga menjadi salah satu permasalahannya. Adapun realisasi penggunaan dana desa di Desa Girirejo tahun 2018 dapat dilihat dari tabel berikut : Tabel 2 Realisasi Penggunaan Dana Desa

\begin{tabular}{|c|c|}
\hline Realisasi Penggunaan Dana Desa & Besaran Dana Desa \\
\hline Pembangunan & Rp. 916.695 .000 \\
\hline Pemberdayaan Masyarakat & Rp. 102.796 .000 \\
\hline Total & Rp. 1.019.491.000 \\
\hline
\end{tabular}

Sumber : Perdes Girirejo, 2019

Sebelumnya telah ada penelitian yang memiliki topik yang serupa dan peneliti jadikan referensi untuk penelitian yang peneliti lakukan. Penelitian pertama dari Enry Ardianto (2016) dengan judul “Analisis Pengelolaan Dana Desa Kampung Ono Harjo dan Kampung Nambah Dadi Kecamatan Terbanggi Besar Kabupaten Lampung Tengah". Penelitian ini menggunakan teori fungsi manajeme dari G.R. Terry dan teori manajemen keuangan daerah dari Waluyo dengan metode penelitian analisis deskriptif kualitatif. Berbeda dengan penelitian yang dilakukan peneliti lebih memfokuskan pada manajemen dana desa dengan menganalisis 
keterlibatan masyarakat dalam manajemen tersebut. Hasil penelitian ini pun dapat dikatakan kedua pemerintahan kampung sudah baik dalam pengelolaan dana desa pada tahun 2015 meskipun belum maksimal.

Penelitian kedua yang relevan adalah penelitian dari Gina Prameswari (2017) yang berjudul “Manajemen Dana Desa di Desa Pejanten Kecamatan Kramatwatu Kabupaten Serang Tahun Anggaran 2015". Penelitian ini menggunakan teori fungsi manajemen dari Luther Gullick dan metode kualitatif pendekatan deskriptif. Sedangkan penelitian yang dilakukan peneliti menggunakan teori dari G.R. Terry dan menggunakan pendekatan studi kasus. Adapun hasil penelitiannya adalah pelaksanaan pengelolaan dana desa di Desa Pejanten tahun anggaran 2015 sudah cukup baik, meskipun masih ada beberapa kekurangan.

Oleh sebab itu peneliti ingin mengetahui sejauh mana manajemen dana desa di Desa Girirejo. Selain itu seperti apa proses penggunaan dana desa tersebut serta bagaimana keterlibatan masyarakat dalam manajemen dana desa tersebut dan faktor apasaja yang mendukung juga menghambat dalam manajemen dana desa.

\section{KAJIAN LITERATUR}

\section{Konsep Manajemen dalam Administrasi Negara}

Konsep manajemen dalam administrasi negara terdapar pada salah satu paradigma perkembangan administrasi negara. Henry (2014) mengungkapkan telah terjadi lima paradigma dalam administrasi negara yaitu;

1. Paradigma 1 (1990-1926): Paradigma politik dan administrasi.

2. Paradigma 2 (1927-1937): Paradigma prinsip-prinsip administrasi.
3. Paradigma 3 (1950-1970): Paradigma administrasi negara sebagai ilmu politik

4. Paradigma 4 (1956-1970): Paradigma administrasi publik sebagai ilmu administrasi.

5. Paradigma 5 (1970-sekarang): Paradigma administrasi publik sebagai administrasi publik.

Prinsip manajemen termasuk kedalam paradigma ke 2 dan dikembangkan pada paradigma ke 4 .

\section{Pengertian Manajemen}

Samsudin (2006) menjelaskan bahwa manajemen adalah bekerja dengan orangorang untuk mencapai tujuan organisasi dengan pelaksanaan fungsi perencanaan, pengorganisasian, penyusunan personalia atau kepegawaian, pengarahan, kepemimpinan dan pengendalian. G.R Terry (Hasibuan, 2009) menyatakan bahwa manajemen adalah suatu proses yang khas yang terdiri dari tindakan-tindakan perencanaan, pengorganisasian, pengarahan, dan pengendalian yang dilakukan untuk menentukan serta mencapai sasaran-sasaran yang telah ditentukan melalui pemanfaatan sumber daya manusia dan sumber-sumber lainnya. Dari pengertian diatas maka peneliti menarik kesimpulan bahwa manajemen merupakan suatu proses yang didalamnya terdapat tindakan-tindakan manusia untuk mencapai tujuan tertentu.

\section{Fungsi Manajemen}

Fungsi manajemen adalah segenap kegiatan yang dilaksanakan untuk mencapai tujuan yang telah ditetapkan dengan cara yang diatur sedemikian rupa sistematis sehingga tujuan dapat tercapai (Salam, 2004). Terdapat beberapa pendapat ahli mengenai fungsi manajemen, dan peneliti menggunakan teori fungsi manajemen dari G.R Terry. Peneliti memilih teori tersebut karena teori dari G.R Terry cocok digunakan antara teori dan 
implementasi dilapangan. Teori fungsi manajemen dari G.R Terry terdiri dari 4 variabel yaitu; (1) Perencanaan (Planning); (2) Pengorganisasian (Organizing);

Pengarahan (Actuating); (4) Pengendalian (Controlling).

\section{Konsep Dana Desa}

Menurut PP No 8 Tahun 2016 tentang dana desa yang bersumber dari Anggaran Pendapatan dan Belanja Negara (APBN) dana desa adalah dana yang bersumber dari APBN yang diperuntukkan bagi desa yang ditransfer melalui APBD Kabupaten/Kota dan digunakan untuk membiayai penyelenggaraan pemerintahan, pelaksanaan pembangunan, pembinaan kemasyarakatan dan pemberdayaan masyarakat. Berdasarkan pasal 2 PP No 8 Tahun 2016 dana desa dikelola secara tertib, taat pada ketentuan peraturan-perundangundangan, efisien, ekonomis dan efektif, transparan, dan bertanggungjawab dengan memperhatikan rasa keadilan dan kepatuhan serta mengutamakan kepentingan masyarakat setempat.

Pada tahun 2018 sendiri dana desa di Kabupaten Magelang disalurkan kedesadesa melalui 3 tahap yakni tahap 1 sebesar 20\%, tahap $240 \%$ dan tahap $340 \%$. Pemerintah melakukan pemantauan dan evaluasi atas pengalokasian, penyaluran, penggunaan dan pelaporan dana desa. Menurut Perbup Magelang No 3 Tahun 2018 terdapat 2 sanksi yang diberikan kepada desa yang tidak memenuhi ketentuan yang telah diatur dalam peraturan yang berlaku yakni sanksi penundaan penyaluran dana desa dan sanksi pemotongan penyaluran dana desa.

\section{METODE PENELITIAN}

Metode penelitian yang digunakan peneliti adalah metode kualitatif dengan pendekatan studi kasus. Untuk pengumpulan data peneliti menggunakan beberapa metode diantaranya; dokumentasi, observasi dan wawancara. Penelitian ini dilakukan pada bulan April 2019 dengan sasaran penelitian kepala desa, aparat desa dan masyarakat Desa Girirejo.

\section{HASIL DAN PEMBAHASAN}

Desa Girirejo secara administratif termasuk dalam wilayah Kecamatan Kaliangkrik, Kabupaten Magelang yang terdiri dari 8 dusun, 26 RT dan 9 RW. 8 dusun diantaranya adalah Dusun Mranggen, Dusun Kebonrejo, Dusun Pagulen, Dusun Tempel Terko, Dusun Kalipan, Dusun Karang Jurang, dan Dusun Candisari. Alasan pemilihan Desa Girirejo sebagai tempat penelitian adalah karena Desa Girirejo merupakan salah satu desa yang mendapatkan dana desa diatas 1 Milyar, dan desa tersebut juga merupakan salah satu desa yang mendapatkan alokasi afirmasi. Alokasi afirmasi yaitu alokasi dana yang diberikan kepada desa tertinggal dan desa sangat tertinggal yang mempunya Jumlah Penduduk Miskin (JPM) tinggi.

\section{Manajemen Dana Desa}

Pada penelitian ini untuk mengetahui manajemen dana desa di Desa Girirejo, peneliti menggunakan teori manajemen George $\mathrm{R}$ Terry yang mengemukakan 4 fungsi manajemen untuk memberikan pandangan mengenai manajemen. Adapun analisis hasil penelitian tersebut adalah sebagai berikut:

\section{Perencanaan}

Perencanaan merupakan proses penentuan tujuan organisasi kemudian menyajikan dengan jelas program, taktik, tata cara pelaksanaan dan tindakan yang diperlukan untuk mencapai tujuan yang telah ditentukan secara menyeluruh. Penetapan strategi guna mencapai tujuan yang telah ditetapkan merupakan bagian dari suatu perencanaan dalam suatu pelaksanaan program atau kegiatan dalam 
organisasi. Dalam penentuan tujuan, perlu disusun pula prioritas utama dan sumber daya yang dimiliki sehingga memudahkan pelaksanaan perencanaan strategi yang akan digunakan. Hasil penelitian dalam perencanaan pada manajemen dana desa di Desa Girirejo dilihat dari penetapan strategi dan program yang dilakukan melalui musyawarah baik ditingkat desa maupun dusun. Selain itu penetapan sasaran dapat dilihat dari penetapan program yang urgent atau prioritas selanjutnya dilakukan verifikasi lapangan untuk menetapkan jumlah anggaran atau besarnya anggaran yang dibutuhkan.

\section{Pengorganisasian}

Pengorganisasian dapat diartikan penentuan atau pembagian tugas kepada orang-orang yang terlibat dalam sebuah organisasi untuk mencapai tujuan. Pengorganisasian juga berkaitan erat dengan perencanaan, karena dalam pengorganisasian pun harus direncanakan. Hasil penelitian dalam pengorganisasian pada manajemen dana desa dilihat dari pembentukan tim pelaksana yang melalui musrenbangdes dan dipilih yang mengetahui atau memahami mengenai pembangunan baik secara teknis dan administrasi. Selain itu penetapan pembagian tugas pada tim pelaksana diserahkan kepada Ketua TPK yang kemudian membagi menjadi TPK dusun dan TPK desa. Pembagian tugas tersebut disesuaikan dengan kebutuhan, diantaranya ada yang bertugas pada bagian administrasi, lapangan dan juga bagian desain. Akan tetapi, Kasi Kesejahteraan selaku penanggungjawab pembangunan dan Kasi Pelayanan selaku penanggungjawab program pemberdayaan masyarakat tidak dilibatkan dalam tim pelaksana kegiatan hanya dilibatkan sebagai pemantau kegiatan saja.

\section{Pengarahan}

Pengarahan artinya membuat semua anggota kelompok agar mau bekerjasama dan bekerja ikhlas serta bergairah untuk mencapai tujuan sesuai dengan perencanaan dan usaha-usaha pengorganisasian. Pengarahan merupakan salah satu fungsi manajemen yang dominan dilakukan dalam sebuah organisasi yang bertujuan agar semua orang yang terlibat mau bekerjasama dalam mencapai tujuan yang diinginkan. Hasil penelitian dalam pengarahan pada manajemen dana desa dilihat dari dua hal. Pertama, pengarahan bagi pegawai dalam pelaksanaan dana desa dilakukan oleh Pendamping Lokal Desa (PLD) juga dari desa itu sendiri yang dilakukan oleh Kepala Desa dan Aparat desa yang lainnya. Kedua, pengarahan bagi aparat dalam penyusunan Laporan Pertanggungjawaban (LPJ) yang juga dilakukan oleh PLD dan dari kecamatan melalui bimbingan teknis yang diikuti oleh aparat desa biasanya diikuti oleh sekretaris desa dan bendahara desa.

\section{Pengendalian}

Pengendalian dapat didefinisikan berbagi proses penentuan, apa yang harus dicapai yaitu standar, apa yang sedang dilakukan yaitu pelaksana, nilai pelaksanaan. Dan apabila perlu melakukan perbaikan-perbaikan, sehingga pelaksanaan sesuai dengan rencana yaitu selaras dengan standar. Pengendalian juga dapat diartikan proses mengendalikan atau mengatur berbagai faktor dalam organisasi agar dapat berjalan sesuai yang direncanakan dan merupakan proses perbaikan apabila terdapat penyimpangan atau ketidaksesuain antara rencana dan tujuan. Hasil penelitian dalam proses pengendalian dilihat dari monitoring dan evaluasi dalam pelaksanaan dana desa dan dalam pembuatan Laporan Pertanggungjawaban (LPJ). Monitoring dan evaluasi dalam pelaksanaan dana desa dengan adanya pemantauan cek fisik dilapangan baik 
secara teknis maupun administrasi. Monitoring dan evaluasi dalam LPJ dengan pemantauan oleh PLD yang dicek secara administrasi dan dilaporkan secara bertahap. Laporan berkala biasanya dilaporkan ke Kementerian Keuangan dan Kementerian Desa, Pembangunan Daerah Tertinggal dan Transmigrasi.

Perbedaan antara rencana penggunaan dan realisasi penggunaan dana desa dikarenakan adanya ketidakselarasan antara Permendagri dengan Siskudes yang mengakibatkan perbedaan program yang dilaksanakan. Selain itu adanya anggaran perubahan yang dilakukan didesa tersebut mengakibatkan adanya perbedaan anggaran dalam perencanaan dengan realisasi yang dilakukan.

\section{Keterlibatan Masyarakat dalam Manajemen Dana Desa}

Pada penelitian ini bukan hanya aparat desa yang terlibat dalam manajemen dana desa melainkan masyarakat juga ikut terlibat dalam manajemen dana desa di Desa Girirejo. Keterlibatan masyarakat tersebut dimulai dari proses perencanaan hingga pengawasan dalam manajemen dana desa. Proses perencanaan yang melibatkan masyarakat adalah proses musyawarah. Musyawarah merupakan proses perundingan atau proses diskusi antara dua orang atau lebih yang dilakukan untuk memperoleh keputusan terbaik. Musyawarah yang melibatkan masyarakat diantaranya musdus (musyawarah dusun) yang mencari gagasan atau ide dan dilanjutkan dengan musdes (musyawarah desa) yang membahas rencana kegiatan desa dan pembentukan tim pelaksana. Musyawarah dilakukan dengan tujuan untuk memberikan kesempatan kepada masyarakat agar lebih aktif berpartisipasi dalam penyusunan rencana kegiatan pembangunan yang ada di desa.
Kegiatan selanjutnya yang melibatkan masyarakat dalam manajemen dana desa adalah dalam pelaksanaan kegiatan. Pelaksana kegiatan dimana masyarakat dilibatkan dalam tim pelaksana kegiatan baik ditingkat desa maupun dusun. Tim Pelaksana Kegiatan (TPK) dusun dibentuk pada saat musyawarah dusun bersangkutan yang akan melaksanakan kegiatan khususnya program pembangunan. TPK desa dibentuk pada saat musyawarah desa dan ditetapkan melalui Surat Keputusan (SK) Kepala Desa untuk melaksanakan kegiatan pembangunan dan pemberdayaan yang ada didesa. Selain sebagai tim pelaksana, pada saat pelaksanaan kegiatan masyarakat juga terlibat sebagai tenaga kerja. Keterlibatan masyarakat sebagai tenaga kerja dalam kegiatan pembangunan biasanya melibatkan masyarakat dusun yang bersangkutan, apabila tenaga kerja tersebut kurang baru diambil tenaga kerja dari dusun lain ataupun dari luar.

Selain kegiatan musyawarah dan pelaksana kegiatan, masyarakat juga dilibatkan dalam proses pengawasan. Pengawasan dapat dikatakan sebagai bentuk kepastian atau untuk menegaskan apakah aktifitas yang telah terlaksana telah sesuai dengan rencana yang sudah dibuat atau tidak. Selain aparat desa, masyarakat juga dapat melakukan pengawasan. Pengawasan oleh masyarakat dapat dilakukan melalui laporan yang disampaikan dalam musyawarah maupun terjun langsung dengan melakukan cek fisik dilapangan. Untuk transparansi anggaran, masyarakat dapat melakukan pengawasan dengan memantau laporan anggaran yang biasanya ditempel di papan pengumuman dan dilakukan oleh aparat desa.

\section{Faktor Pendukung dan Penghambat dalam Manajemen Dana Desa}

Faktor pendukung dalam manajemen dana desa adalah Sumber Daya Manusia 
(SDM), Sumber Daya Alam (SDA) dan Sarana dan Prasarana. SDM yang menjadi faktor pendukung diantaranya, aparat desa, KPMD, TPK serta masyarakat itu sendiri. Aparat desa yang telah memahami dan menjalankan tugas dan fungsi masingmasing dan sesuai dengan peraturan yang ada sangat membantu dalam proses administrasi pada manajemen dana desa. KPMD dan TPK yang dibentuk melalui musyawarah yang melaksanakan tugasnya dengan baik sebagai pelaksana kegiatan baik dalam bidang pembangunan maupun pemberdayaan didesa juga sangat mendukung dalam pelaksanaan pembangunan dan pemberdayaan yang ada didesa. KPMD dan TPK dapat melakukan tugasnya dengan baik tidak terlepas karena telah adanya pelatihan yang mereka ikuti sehingga mereka sangat memahami dalam pelaksanaan kegiatan tersebut. Masyarakat juga menjadi salah satu SDM yang mendukung dalam manajemen dana desa, hal tersebut dapat terlihat dari kegiatankegiatan dan keikutsertaan dalam tim pelaksana kegiatan dan pengawasan dalam manajemen dana desa.

Sumber Daya Alam (SDA) yang menjadi faktor pendukung dalam manajemen dana desa ini adalah faktor tanah yang mempermudah dalam pelaksanaan kegiatan pembangunan dan adanya material batu yang juga membantu dalam proses pembangunan. Sarana dan Prasarana seperti peralatan kantor juga dapat dikatakan sebagai faktor pendukung, karena hal tersebut telah mempermudah aparat desa dalam manajemen dana desa dibidang administrasi.

Faktor penghambat dalam manajemen dana desa adalah pelaksanaan kegiatan dan Sumber Daya Manusia (SDM). Manajemen dana desa tidak terlepas pada pelaksanaan kegiatan terutama pelaksanaan kegiatan pembangunan fisik. Hambatan yang dialami dalam pelaksanaan kegiatan diantaranya masalah cuaca yang tidak dapat dihindari karena takdir yang tidak dapat diperkirakan. Material yang kurang atau tidak ada saat dibutuhkan juga menjadi kendala dalam pelaksanaan kegiatan. Selain itu medan yang dikerjakan terkadang medan atau tempat yang sulit dijangkau juga seringkali menjadi hambatan dalam pelaksanaan kegiatan.

SDM dapat menjadi faktor pendukung maupun penghambat. Tenaga kerja yang diambil dari masyarakat seringkali bukan tenaga kerja yang handal dalam pembangunan fisik sehingga menyebabkan pembangunan fisik yang dilakukan kurang mengalami kemajuan. Selain itu, kesalahpahaman mengenai pajak dan prioritas penggunaan dana desa masih sering terjadi di masyarakat.

\section{PENUTUP}

Berdasarkan hasil dan pembahasan mengenai manajemen dana desa di Desa Girirejo dapat ditarik kesimpulan bahwa manajemen dana desa yang meliputi perencanaan, pengorganisasian, pengarahan, dan pengendalian di Desa Girirejo telah berjalan dengan baik. Namun dalam pengorganisasian Kasi yang bertanggungjawab dalam program yang berkaitan tidak dilibatkan dalam TPK, hanya sebagai pemantau saja. Selain itu masih adanya perbedaan antara rencana dan realisasi yang disebabkan adanya ketidakselarasan Permendagri dengan Siskudes dan adanya anggaran perubahan yang dilakukan didesa tersebut.

Keterlibatan masyarakat dalam manajemen dana desa di Desa Girirejo terlihat dari keterlibatan dalam musyawarah, TPK dan pengawasan dalam proses monitoring dan evaluasi. SDM dapat menjadi faktor pendukung dan penghambat dalam manajemen dana desa selain SDA, dan sarana prasarana sebagai faktor 
pendukung dan pelaksanaan kegiatan sebagai faktor penghambat.

Berdasarkan kesimpulan mengenai manajemen dana desa di Desa Girirejo, Kecamatan Kaliangkrik, Kabupaten Magelang tahun 2018 peneliti memberikan saran sebagai berikut:

1. Perlu melibatkan Kasi yang bertanggungjawab dalam pelaksanaan kegiatan.

2. Perlu adanya keselarasan antara Permendagri dengan Siskudes.

3. Perlu meningkatkan kualitas dan motivasi terhadap masyarakat.

4. Perlu meningkatkan sarana dan prasarana.

5. Adanya pemerataan dalam pembangunan dan pemberdayaan.

\section{DAFTAR PUSTAKA}

\section{Buku:}

Hasibuan, Malayu S.P. (2009). Manajemen Dasar, Pengertian, dan Masalah. Jakarta : PT Bumi Aksara.

Sadili, Samsudin. (2006). Manajemen Sumber Daya Manusia. Bandung: Pustaka Setia Salam, Dharma Setyawan. (2004). Manajemen Pemerintah Indonesia. Jakarta : Djambatan.

\section{Jurnal:}

Endry Ardianto. (2016). Skripsi: Analisis Pengelolaan Dana Desa Kampung Ono Harjo dan Kampung Nambah Dadi Kecamatan Terbanggi Besar Kabupaten Lampung Tengah. Bandar Lampung: Universitas Lampung.

Gina Prameswari. (2017). Skripsi: Manajemen Dana Desa di Desa Pejanten Kecamatan
Kramatwatu Kabupaten Serang Tahun Anggaran 2015. Serang : Universitas Sultan Ageng Tirtayasa.

\section{Peraturan perundang-undangan:}

Peraturan Pemerintah No 8 Tahun 2016 tentang Perubahan PP No 60 Tahun 2014 tentang Dana Desa yang Bersumber dari Anggaran Pendapatan dan Belanja Negara.

Peraturan Desa Girirejo No 01 Tahun 2017 tentang Laporan Pertanggungjawaban Realisasi Pelaksanaan Anggaran Pendapatan dan Belanja Desa Tahun Anggaran 2016.

Peraturan Bupati Magelang No 3 Tahun 2018 tentang Tata Cara, Pembagian dan Penetapan Rincian Dana Desa Setiap Desa Kabupaten Magelang Tahun Anggaran 2018.

Peraturan Desa Girirejo No 01 Tahun 2018 tentang Laporan Pertanggungjawaban Realisasi Pelaksanaan Anggaran Pendapatan dan Belanja Desa Tahun Anggaran 2017.

Peraturan Desa Girirejo No 02 Tahun 2018 tentang Anggaran Pendapatan dan Belanja Desa Tahun Anggaran 2018.

Peraturan Desa Girirejo No 01 Tahun 2019 tentang Laporan Pertanggungjawaban Realisasi Pelaksanaan Anggaran Pendapatan dan Belanja Desa Tahun Anggaran 2018.

Undang-Undang No. 6 Tahun 2014 tentang Desa. 